\title{
POCZĄTKI DZIALALNOŚCI DOMU REKOLEKCYJNEGO OO. JEZUITÓW W CZECHOWICACH-DZIEDZICACH
}

Rzadko kiedy w swojej historii jezuici zakładali dom w tak pomyślnych okolicznościach, jak ten w Dziedzicach ${ }^{1}$. Z polecenia o. prowincjała Włodzimierza Ledóchowskiego do poszukiwania i nabycia odpowiedniego miejsca pod dom rekolekcyjny został wyznaczony rektor Kolegium Krakowskiego, o. Antoni Boc ${ }^{2}$. W listopadzie 1903 roku przybył do Czechowic, gdzie przyjął go bardzo gościnnie proboszcz parafii św. Katarzyny, ks. Ryszard Jarosz i zachęcił do osiedlenia się w Czechowicach. Równi życzliwie byli nastawieni do jezuitów ks. proboszcz Ludwik Vogt z Ćwiklic oraz ks. Franciszek Zuber, rodak. Dzięki pomocy ks. Jarosza znaleziono dwóch benefaktorów domu rekolekcyjnego. Jeden ofiarował 10.000 złr. i ułatwił zakup 6-morgowej parceli, którą nabyto kontraktem w Bielsku 22 lutego 1904 roku, drugi natomiast ofiarował 40.000 złr. na wybudowanie dwupiętrowego gmachu z kaplicą, wielką salą rekolekcyjną i jadalnią, z sypialniami i 36 pokojami dla rekolektantów oraz 5 pokojami dla jezuitów ${ }^{3}$. W celu zakończenia budowy domu oraz jego wyposażenia (np. założe-

W 1880 r. Czechowice (niem. Czechowitz) i Dziedzice (niem. Dzieditz, Dziedzitz) były położonymi obok siebie wioskami należącymi do powiatu i dekanatu bielskiego na Śląsku austriackim. Czechowice liczyły 2632 mieszkańców. Natomiast położone nad rzeką Białą Dziedzice miały stację kolejową, przez którą przechodziła kolej żclazna Wiedeń-Kraków oraz połączenia kolejowe: Dziedzice-Wrocław i Dziedzice-Bielsko. Dziedzice leżą $8 \mathrm{~km}$ od Pszczyny, $49 \mathrm{~km}$ od Szopieniec, $65 \mathrm{~km}$ od Bytomia, $162 \mathrm{~km}$ od Kluczborka, $252 \mathrm{~km}$ od Wrocławia, 327 $\mathrm{km}$ od Wiednia, $85 \mathrm{~km}$ od Krakowa i 11 od Bielska. Dziedzice należały do parafii katolickiej Czechowice. Zwróćmy uwagę, że w niektórych publikacjach Dom Rekolekcyjny w Dziedzicach jest podawany zamiennie jako dom 4. Czechowicach. Slownik geograficzny Królestwa Polskiego i innych krajów slowiańskich, red. F. Sulimierski i in., Warszawa 1880-1881, t. I, s. 778; t. II, s. 270.

- Boc Antoni (1862-1914), profesor religii, języka lacińskiego i niemieckiego w Chyrowie (1889-1900), rektor w Nowym Sączu (1900-1901) i Krakowie (1901-1906), misjonarz wśród emigrantów polskich w Stanach Zjednoczonych Ameryki Północnej (1906-1913). Znany kaznodzieja i rekolekcjonista. Encyklopedia wiedzy o jeziirach na ziemiach Polski i Litwy 1564-1995, oprac. L. Grzebień przy współpracy zespołu jezuitów, Kraków 1996. s. $51-52$ (dalej cytuję jako: Ençklopedia wiedzy o jezuitach).

Diariusz Domu Towarzustwa Jezusowego w Dziedzicach 1940-1949, Archiwum Towarzystwa Jezusowego w Krakowie rkps 3292, s. I (dalej cytuję jako: ATJKr.); S. Załęski, Jezuici w Polsce, t. V/2, Kraków 1906, = 1129 Na wieść o nabyciu gruntów pod budowę domu w Czechowicach pojawiły się pogłoski, że jezuici galicyiscy. zakupili w Czechowicach kilkanaście morgów gruntu. gdzie z wiosną zaczną budować kościół i duży 
nia instalacji elektrycznej), przełożeni musieli zaciągnąć w banku pożyczki, które następnie spłacali do 1919 roku, współpracując w tej sprawie z prokuratorem prowincji o. Franciszkiem Stecem ${ }^{4}$.

Zwolennikiem nowej placówki Towarzystwa Jezusowego w Czechowicach okazał się książę-biskup wrocławski, kard. Georg Kopp ${ }^{5}$, który poparł budowę i przyjął protektorat nad domem oraz wyjednał u prezydenta Śląska austriackiego hrabiego Thuna pozwolenie na osiedlenie jezuitów w Dziedzicach. Warto dodać, że kard. Kopp znał i korzystał z pomocy jezuitów. O. Józef Lipski ${ }^{6}$, który wstąpił do jezuitów jako ksiądz diecezjalny - podobnie jak kaznodzieja i rekolekcjonista 0 . Władysław Długołęcki ${ }^{7}$ - był thumaczem kard. Koppa podczas wizytacji kanonicznej, która odbyła się w dniach 4-19 maja 1909 roku w diecezji wrocławskiej. O. Lipski przetłumaczył wówczas na język polski 61 przemówień kard. Koppa ${ }^{8}$.

Pierwszy plan budowy Domu Rekolekcyjnego w Czechowicach sporządził br. Stanisław Dydek ${ }^{9}$. Plan ten nie zyskał aprobaty władz zakonnych. 11 czerwca 1904 roku o. generał Ludwik Martin zatwierdził plan budowy przygotowany przez dwóch budowniczych z Bielska Jüttnera i Bolka ${ }^{10}$. Budowę domu z kaplicą na 500 osób roz-

klasztor dla wypędzonych z Francji zakonników. Przy zakupie gruntów dla jezuitów francuskich pośredniczyć miał ks. Stanisław Stojałowski, który był w młodości swej członkiem zakonu jezuickiego". List o. J. Rotha do o. prowincjała W. Ledóchowskiego, Karwina, 23 II 1904, Czechowice-Dziedzice, Dom Rekolekcyjny, ATJKr. rkps 382, s. 43.

${ }^{4}$ Listy o. F. Czarlińskiego do prokuratora prowincji o. F. Steca, Dziedzice, lata 1910-1912, Czechowice-Dziedzice, Dom Rekolekcyjny, ATJKr. rkps 382, s. 3-32; Legaty, spadki, pożyczki zaciagnięte przez domy Prowincji Galicyjskiej Towarzystwa Jezusowego w latach 1876-1925, ATJKr. rkps 2002. s. 361-385.

${ }_{5}^{5}$ Kopp Georg (1837-1914), biskup Fuldy (od 1881), potem biskup wroclawwski (od 1887), kardynał (1893), członck pruskicj Rady Państwa i Izby Panów, austriackiej Izby Panów i sejmu w Opawie. S. Załęski, Jezuici w Polsce. W skróceniu, Kraków 1908, s. 309, A. Galos, Kopp Georg, Slownik biograficzmy katolickiego duchowieństwa ślqskiego XZX i XX wieku, pod red. M. Patera, Katowice 1974, s. 188-192 (dalej cytuje jako: SBKDS). Kard. Kopp położył wielkie zasługi dla rozwoju życia religijnego w diecezji wrocławskiej, natomiast „w stosunku do ludności polskiej popierał jednak metodę germanizacji w wybitnym stopniu". W. Urban, Zarys dziejów diecezji wroclawskiej, Wrocław 1962, s. 199.

${ }^{6}$ Lipski Józef (1860-1935), m.in. misjonarz na terenie Śląska oraz superior w Cieszynie (1904-1906), operariusz (1906-1907) a następnie superior w Czechowicach (1907-1910), misjonarz ludowy w Cieszynie (1910-

1913), a równocześnie misjonarz sezonowy wśród robotników w Niemczech (1911-1913). Ponownie superior w Czechowicach (1913-1915). Encyklopedia wiedzy o jezuitach, s. 365; L. Grzebień, Lipski Józef, SBKDS, s. 236-237.

Długołęcki Władysław (1854-1905) m.in. profesor teologii dogmatycznej i apologetycznej w Widnawie na Śląsku (1901-1903). W trakcie pobytu w Widnawie byl thumaczem kazań kard. Koppa podczas wizytacji pasterskich w środowiskach polskich. Autor żywotów świętych, artykułów religijnych w „Katoliku” i wielu pieśni religijnych, manych głównie na Śląsku. H. Haduch, O. Whadyslaw Diugołęcki, ,Nasze Wiadomości" 2 (1906-1909), s. 254 256; Encyklopedia wiedzy o jezuitach, s. 124-125; L. Grzebien, Dlugotęcki W7adyslaw, SBKDS, s. 86-87.

${ }^{8}$ „Nasze Wiadomości” 3 (1910-1912), s. 191; J. Kwiatek. Związi Gómego Sląska z Galicja na przetomie XIX i XX wieku, Opole 1994, s. 77, 79.

"Dydek Stanisław (1864-1925), stolarz, nauczył się zawodu budowlanego pod kierunkiem inż. Krzyżanowskiego i prof. Kovatza. Kierował budowami i remontami domów i kościołów w Prowincji Galicyjskiej (później Polskiej). Encyklopedia wiedzy o jezuitach, s. 138.

${ }^{10}$ Zob. plany budowy domu w Czechowicach oraz Lageplan über die zur Darstellung Grundstücke E.Z. 407 und 512 der Katastralgemeinde Czechowitz. C-echowice-Dziedtice. Dom Rekolekcyjnł: ATJKr. rkps 382, s. 85-86, 103. 
poczęto na początku lipca tegoż roku. Park został założony przez ogrodnika z Bielska Franciszka Chlupacza. Budową domu kierował o. Franciszek Smarzły ${ }^{11}$, który przybył do Dziedzic 6 lipca 1904 roku i zamieszkał na probostwie u ks. Ryszarda Jarosza, pomagając jednocześnie jemu i sąsiednim proboszczom w pracy parafialnej. O. Smarzły dokonał także poświęcenia kamienia węgielnego pod dom. Uroczystość odbyła się cicho 21 lipca 1904 roku. Pod koniec listopada 1905 roku była już gotowa i możliwa do zamieszkania środkowa i wschodnia część dużego gmachu. W następnym roku dobudowano część zachodnią ${ }^{12}$.

Dnia 8 października 1905 roku przyjechał do Dziedzic pierwszy przełożony domu, o. superior Łukasz Łaszczyk ${ }^{13}$, który w dzień wspomnienia św. Stanisława Kostki, 13 listopada 1905 roku, odprawił pierwszą Mszę św. w jednej z sal. W ślad za o. Łaszczykiem przybyli: o. Paweł Makowski ${ }^{14}$ i br. Piotr Michałowski ${ }^{15}$. Uroczystego otwarcia dwupiętrowej rezydencji i Domu Rekolekcyjnego oraz poświęcenie kaplicy dokonał w Uroczystość Niepokalanego Poczęcia Najświętszej Maryi Panny, 8 grudnia 1905 roku, ks. Ryszard Jarosz. W ceremonii wzięły udział plutony straży ogniowej $i$ weteranów, thum wiernych oraz sławna w tym regionie kapela londzinowska $\mathrm{z} \mathrm{Za}-$ brzega. Podczas sumy sprawowanej przez ks. Jarosza w kaplicy publicznej pw. św. Józefa kazanie wygłosił o. Paweł Makowski, a procesję z Najświętszym Sakramentem poprowadził dookoła domu najstarszy wiekiem ks. Tobiasz Grünwald z Zabrzega. „Uradowany tym lud śląski, rozniósł po okolicy wesołą nowinę, że w Czechowicach jest klasztor, w którym nie tylko księża i panowie, ale i robotnicy rekolekcje odprawiać mogą swobodnie"16. Od tego czasu przyjęło się, że Dom Rekolekcyjny nazywany był klasztorem.

Należy podkreślić, że był to nie tylko pierwszy dom rekolekcyjny jezuitów polskich, ale także pierwszy dom rekolekcyjny na ziemiach Polski. Wkrótce potem, w 1908 roku, na przeciwległym biegunie Prowincji Galicyjskiej, we Lwowie przy ul. Dunin-Borkowskich 11, z inicjatywy superiora rezydencji lwowskiej o. Stanisława Sopucha ${ }^{17}$, został otwarty drugi dom rekolekcyjny, który miał shużyć religijnemu od-

${ }^{11}$ Smarzły (Smarsły, Zmarzły) Franciszek (1861-1936), m.in. profesor języka niemieckiego w Tarnopolu (1885-1887) i Chyrowie (1887-1892 i 1895-1898), kaznodzieja polski i niemiecki w Czemiowcach (1900-1901), minister i operariusz w Krakowie (1902-1904) i Czechowicach (1904-1907, 1908-1910, 1918-1919 i 1928-1936). Encyklopedia wiedzv o jezuitach, s. 626; „Wiadomości z Prowincji” 4 (8) (1936), s. $2-3$.

${ }^{12}$ K. Feliś, Domy rekolekcyjne $i$ dom rekolekcyjny w Czechowicach, ATJKr. rkps 1626, s. 275; Diariusz Domu Towarzystwa Jezusowego w Dziedzicach 1940-1949, ATJKr. rkps 3292, s. 1-2; Schematismus Bistums Breslau und seines Delegatur=Bezirks für das Jahr 1906, s. 107.

${ }^{13}$ Laszczyk Lukasz (1848-1928), m.in. superior w Czechowicach (1905-1906), prokurator Wydawnictwa Apostolstwa Modlitwy w Krakowie (1906-1908), sekretarz prowincjała (1908-1915), wicerektor w Czechowicach (1915-1916), duchowny domu w Staniątkach oraz Krakowie (1916-1928). Encyklopedia wiedzy o jezuitach, s. 385 .

${ }^{14}$ Makowski Paweł (1844-1920), misjonarz, kaznodzieja w Nowym Sączu, Czerniowcach i Cieszynie, duchowny w Krakowie, Czechowicach, Lwowie i Starej Wsi. Tamże, s. 401.

${ }^{15}$ Michałowski Piotr, br., ur. 1877, wst. 1897, zm. 1951. Tamże, s. 843.

${ }^{16}$ S. Załęski, Jezuici w Polsce, t. V/2, s. 1129-1130.

${ }^{17}$ Sopuch Stanisław (1869-1941), m.in. operariusz, kaznodzieja i organizator stowarzyszeń robotniczych w Krakowie i Lwowie, superior rezydencji (1904-1908 i 1913-1915) oraz domu rekolekcyjnego (1908-1913) we 
rodzeniu narodu. Patronem domu został także św. Józef. Ojcowie Domu Rekolekcyjnego we Lwowie udzielali rekolekcji w języku polskim i rosyjskim. Ich uczestnikami byli polscy, ukraińscy i rosyjscy księża i klerycy oraz mężczyźni wszystkich stanów i zawodów ${ }^{18}$. „Oby one były prawdziwemi duchowemi zdrojowiskami dla naszego społeczeństwa"19 - wyrażał życzenie w 1909 roku jezuita polski, o. Karol Feliś.

O. Karol Feliś ${ }^{20}$ pozostawił nam pochodzący $z 1909$ roku opis domu czechowickiego $i$ jego otoczenia, który warto przytoczyć w całości: dom „wspaniale przedstawia się oku, zbudowany na nieznacznym wzniesieniu panuje swymi rozmiarami nad całą okolicą, cichy i samotny, bez bliskiego sąsiedztwa innych zabudowań mieszkalnych, istotnie spokojne ustronie rekolekcyjne. Przez wielkie, umieszczone w samym środku gmachu, odrzwia wstępujemy do wielkiej, jasnej kaplicy. Uwagę widza przyciąga do siebie obraz prawie naturalnych rozmiarów, malowany na płaszczyźnie niszy wielkiego ołtarza. Obraz mówi do nas głęboką symboliczną treścią. Przy Bożym Dzieciątku, trzymanym przez siedzącego na bramie św. Józefa skupiają się dwie grupy Świętych: z lewej strony Święci, którzy odrodzili się do nowego życia przez wielką pokutę, zaś z prawej strony Święci, którzy całe życie służyli wiernie i niewinnie P. Bogu. Widok obrazu budzi mimo woli w sercu uczucie żalu za sprzeniewierzenie się Bogu, uczucie błogiej nadziei i wiary w miłosierdzie Zbawcy. - Po bokach znajdują się jeszcze ołtarze Niepokalanej Dziewicy i Najświętszego Serca P. Jezusa. Do kaplicy prowadzą również dwa wejścia $z$ korytarza dolnego i jedno $\mathrm{z}$ pierwszego piętra na chór, które każdej chwili udogadniają odprawiającym rekolekcje dostęp do kaplicy. Wnętrze domu rekolekcyjne urządzone odpowiednio do potrzeb rekolekcyjnych na wzór podobnych domów zagranicznych. Oprócz pokojów, zamieszkiwanych przez przebywających stale $\mathrm{w}$ domu rekolekcyjnym XX. Jezuitów, są dwie obszerne sypialnie, jako też blisko 40 pokojów pojedynczych. W sypialniach wspólnych umieszcza się gości tylko w tym wypadku, kiedy liczba ich przekracza ilość pokojów osobowych.

Lwowie. Prowincjał Prowincji Galicyjskiej a następnie Polskiej (1919-1926). Doskonały organizator i kaznodzieja. Encyklopedia wiedzy o jezuitach, s. 633.

${ }^{18}$ Jak zaznacza o. Józef Brząkalski, wzorem dla lwowskiego Domu Rekolekcyjnego były domy jezuitów angielskich, holenderskich, belgijskich i austriackich. 30 VIII 1908, podczas uroczystości poświęcenia domu we Lwowie, zabrał głos o. prowincjal Włodzimierz Piątkiewicz. Warto w tym miejscu przytoczyć jego wypowiedź, albowiem bez wątpienia odnosi się ona także do Domu Rekolekcyjnego w Dziedzicach: „W czasach, w których tak dotkliwie odczuwamy wśród szerszych warstw społeczeństwa brak ludzi o silnych, wybitnych charakterach, na których by pracę nad odrodzeniem narodu oprzeć można - ufamy, że dom ten rekolekcyjny stanie się nie na ostatnim miejscu szkołą tego właśnie rodzaju charakterów i ludzi. Ufamy, że wychodzić stąd będą rok za rokiem daj Boże, miesiąc za miesiącem - jeśli nie zastępy, to pewnie grupy mężów, którzy w społeczeństwie nieść będą zdrowie moralne $\mathrm{i}$ cnotę; jasną, prostą a dzielną afirmację zasad najbardziej podstawowych, a zatem najbardziej doniosłych; a wraz z zasadami także zapał wielki szerzenia i bronienia ich, ten zapał, który tworzy cudy!". J. Brząkalski, Dom rekolekcyjny we Lwowie, „Nasze Wiadomości” 2 (1906-1909), s. 488; R. Koppens, Domy rekolekcyjne, ,Nasze Wiadomości” 6 (1921), s. 5-8.

${ }^{19} \mathrm{~K}$. Feliś, Domy rekolekcyjne i dom rekolekcyjny w Czechowicach, ATJKr. rkps 1626, s. 261.

${ }^{20}$ Feliś Karol (1881-1912), studiował archeologię chrześcijańską na Uniwersytecie Jagiellońskim w Krakowie (1909-1910), Wiedniu (1910-1911) oraz Rzymie (1911-1912). Mimo krótkiego zycia ogłosił kilkanaście broszur i artykułów z dziedziny teologii, archeologii oraz ascezy. Encyklopedia wiedzy o jezuitach, s. 153; K. Konopka, O. Karol Feliś, „Nasze Wiadomości” 5 (1918), s. 97-108. 
W' ogóle dom czechowicki może pomieścić na rekolekcje około 80 osób. Poza tym Jom posiada dwie sale wykładowe, $z$ których jedna mniejsza a druga o tych samych rozmiarach, jak kaplica. Prawie naokoło całego budynku rozprzestrzenia się wielki, ミmorgów ziemi zajmujący ogród, urządzony na modłę angielskich parków. Bardzo liczne, pokrzyżowane i prowadzone między rozmaitymi drzewami i krzewami, ścieżki pozwalają wielkiej liczbie gości korzystać z ogrodu, w spokoju i ciszy, bez wzajemnego przeszkadzania sobie. $Z$ biegiem czasu, kiedy drzewa jeszcze bardziej wzrosną, ogród ten będzie nie tylko wspaniałą ozdobą okolicy, ale nada zarazem domowi rekolekcyjnemu w wysokim stopniu charakter prawdziwego zacisza, jakby stworzonego w tym celu, by tu z dala od zgiełku i codziennego gwaru skupić swego ducha, nabrać sił do życia" ${ }^{21}$.

Kilkanaście lat później, nie ukrywając, że Prowincja Galicyjska otwierając domy rekolekcyjne w Czechowicach i Lwowie poszła za przykładem jezuitów z Europy zachodniej, o. Romuald Koppens ${ }^{22}$ wyraził na łamach czasopisma zakonnego .Nasze Wiadomości" myśli, które nie straciły nic ze swojej aktualności i stanowią swego rodzaju program jezuickich domów rekolekcyjnych: „W ten sposób powstały w XX. w. dwa niby sanatoria dusz, które miały spełniać jedno z najważniejszych zadań naszych Konstytucji [zakonnych]: mianowicie, różne klasy społeczne tak duchowne jak świeckie wyrabiać, doskonalić i utrwalać w życiu i działaniu katolickim za pomocą Ćwiczeń duchownych św. Ignacego jako broni najtęższej i najskuteczniejszej, bo od lat 360 wypróbowanej. Praca ta nabierała szczególnej doniosłości przez to, że w takich domach można było Ćwiczenia duchowne odprawiać na osobności, w oderwaniu od codziennej szarzyzny życia; a nad to, że nie tylko całe grupy ludzi jednego zawodu, ale i jednostki mogły się im oddawać; a więc praca ta nabierała przez to cech indywidualnej kultury duszy, co w naszych czasach jest jednym z pierwszorzędnych postulatów pogłębienia życia religijno-moralnego" ${ }^{\text {"23. }}$.

W Domu Rekolekcyjnym w Czechowicach prowadzono rekolekcje indywidualne i stanowe, głównie dla robotników i duchowieństwa ze Śląska austriackiego i niemieckiego, a także Śląska Cieszyńskiego, Galicji i Królestwa. Dzięki położeniu na pograniczu austriacko-niemieckim Dom Rekolekcyjny umożliwiał jezuitom podjęcie szerokiej działalności kaznodziejskiej w środowisku robotniczym, narażonym na dechrystianizację wskutek problemów społecznych, jakie rodził dynamiczny w tym czasie rozwój przemysłu i proces powstawania dużych aglomeracji miejskich. Dzieło rekolekcji dla robotników spotkało się z pełną aprobatą ze strony papieży: Leona XIII (,papieża robotników") oraz jego następcy Piusa X. Należy przy tym podkreślić, że bramy jezuickich domów rekolekcyjnych były zawsze otwarte dla przedstawicieli

\footnotetext{
${ }^{21}$ K. Feliś, Domy rekolekcyjne i dom rekolekcyjny w Czechowicach, ATJKr. rkps 1626, s. 276-277.

${ }^{22}$ Koppens Romuald (1865-1943), od 1893 długoletni profesor literatury polskiej i języka greckiego w Zakładzie Naukowo-Wychowawczym w Chyrowie, gdzie wychował i wykształcił wielu wybitnych literatów, publicystów i historyków literatury. Współpracował z „Przeglądem Powszechnym” i z Komisją Języka Polskiego PAU. Encyklopedia wiedzy o jezuitach, s. 302.

${ }^{23}$ R. Koppens, Domy rekolekcyjne, ,Nasze Wiadomości” 6(1921), s. 3-4.
} 
wszystkich warstw społecznych. Już w 1906 roku jezuici z Czechowic rozpoczęli udzielanie w Domu Rekolekcyjnym rekolekcji także dla niewiast (matek, dziewcząt, pań $\mathrm{z}$ inteligencji), które na ten czas nocowały początkowo $\mathrm{u}$ gospodarzy czechowickich (nieraz po 20,30 i więcej osób $\mathrm{w}$ jednym domu), a następnie w pomieszczeniach klasztoru sióstr felicjanek w Dziedzicach ${ }^{24}$.

Lokalizacja domu była zatem rezultatem rozeznania dokonanego przez o. prowincjała Włodzimierza Ledóchowskiego i jego doradców (konsultorów). Pisze o tym o. Feliś: „Dlaczego [pierwszy dom rekolekcyjny na naszej ziemi] stanął w Czechowicach? - Ponieważ dom ów miał na pierwszym miejscu służyć religijnym potrzebom robotnika, więc musiał stanąć tam, gdzie robotnika najwięcej, musiał stanąć w jakimś wielkim ognisku przemysłowym. Jakoż istotnie Czechowice, oddalone tylko o $10 \mathrm{mi}$ nut drogi od Dziedzic, wybornie odpowiadają temu zadaniu. Wszak leżą jakby w środku wielkich obszarów przemysłowych Śląska austriackiego i pruskiego, Galicji i Królestwa Polskiego. Dzięki temu położeniu jak również ożywionej bardzo komunikacji kolejowej w tych stronach może wygodnie do Czechowic zjeżdżać robotnik ze wszystkich tych dzielnic" ${ }^{25}$.

O. Karol Feliś, który sam dawał rekolekcje oraz odwiedził Dom Rekolekcyjny w Czechowicach, żarliwie zachęcał swoich współbraci zakonnych do zaangażowania się na polu rekolekcji, nie tylko tych przeprowadzanych podczas misji ludowych, w okresie Wielkiego Postu bądź dla wspólnot kapłańskich lub zakonnych, lecz także i tych udzielanych od przeszło trzech wieków metodą św. Ignacego Loyoli w domach rekolekcyjnych, które jako pierwsi otworzyli w latach 90-tych XIX wieku jezuici w Belgii i Francji ${ }^{26}$. Wiadomości o seriach rekolekcji, ,które prawdziwie mają moc leczenia i podnoszenia na wyżyny duszy ludzkiej [...] i nie są płodem jakiejś niezdrowej pobożności, ale konieczną potrzebą słabości ludzkiej, niewymuszonym zwyczajem tych, co nie lubią iść przez życie po omacku, co umieją więcej wymagać od siebie"27, zamieszczali jezuici $\mathrm{z}$ wyprzedzeniem $w$ gazetach, bądź przesyłali bezpośrednio do proboszczów i urzędów parafialnych, kierowników szkół oraz różnych organizacji i stowarzyszen katolickich. W zaproszeniach na rekolekcje przesyłanych do proboszczów dołączona była prośba o ,rozgłoszenie i polecenie tychże w swojej parafii”. Natomiast w tych zaadresowanych do kierowników szkół przypominano, że dla nauczycieli pragnących odprawić rekolekcje „według okólnika c. k. Rady szkolnej krajowej

\footnotetext{
${ }^{24}$ Czechowice-Dziedzice, Dom Rekolekcyjny, ATJKr. rkps 382, s. 52, 66, 68, 70-73, 97, 117-119; ,Nasze Wiadomości” 2 (1906-1909), s. 205-206.

${ }^{25}$ K. Feliś, Domy rekolekcyjne i dom rekolekcyjny w Czechowicach, ATJKr. rkps 1626, s. 274; J. Kwiatek, Zwiqzzki Górnego Ślqska z Galicja na przelomie XIX i XX wieku, s. 78. Zdaniem Jerzego Gizy dodatkowym czynnikiem przemawiających za lokalizacją domu rekolekcyjnego w Czechowicach miała być także większa aktywność w okresie pierwszych lat XX wieku lokalnej społeczności protestanckiej, która wieńcząc długoletnie starania w 1911 r. oddała do użytku Ewangelicki Dom Modlitwy z kaplicą. J. Giza, Śladami św. Andrzeja Boboli po Czechowicach-Dziedzicach, Czechowice-Dziedzice 2005, s. 118; S. Gajdzica, A. Londzin, Szkice z dziejôw Parafii Ewangelickiej w Czechowicach-Dziedzicach, Bielsko-Biała 1998, s. 14-16.

${ }^{26} \mathrm{~K}$. Feli ś, Domy rekolekcyjne i dom rekolekcyjny w Czechowicach, ATJKr. rkps 1626, s. 260.

${ }^{27}$ Tamże, s. 255, 256.
} 
z dnia 28. marca 1911 r. L. 4935/I c.k. Rady szkolne tak okręgowe jak miejscowe są upoważnione do udzielania potrzebnego urlopu"28. Po uprzednim porozumieniu z przełożonym domu, najpóźniej w przeddzień ich rozpoczęcia, rekolekcje - „to wielsie dzieło katolickie ostatnich czasów" ${ }^{\prime 29}$ - mogły odprawiać zarówno osoby pojedynzze, jak też i większe grupy.

Nie znaczy to, że idea odprawiania rekolekcji osobno, w domach rekolekcyjnych, przyjęta została bez zastrzeżeń. Nawet w kręgach jezuickich niektórzy zwracali uwagę, że rekolekcje są urządzane co roku w kościołach, a więc po co jeszcze domy rekolekcyjne? Odpowiadając na to zastrzeżenie, o. Feliś dowodził, że istnieje olbrzymia różnica między rekolekcjami w osobnych domach, gdzie panuje niezwykła atmosfera (cisza, samotność i zupełnie skupienie), a rekolekcjami (misjami ludowymi) przeprowadzanymi corocznie w parafii, w których uczestniczą wierni wykonujący codzienną pracę, zanurzeni w gwarze i zgiełku życia codziennego. Tak pisał: „Kiedy w r. 1906 skończyła się z początkiem listopada seria rekolekcji księży w Czechowicach, wówczas wielu ze starszych już kapłanów mówiło, że dopiero po raz pierwszy odprawili prawdziwe rekolekcje. Wszak oni i przedtem już często odprawiali rekolekcje, a jednak wyznali, że rekolekcje w domu rekolekcyjnym były ich pierwszymi prawdziwymi rekolekcjami-Tak, inaczej wyglądają rekolekcje w osobno w tym celu budowanych domach, gdzie wszystkie potrzeby odprawiających Ćwiczenia duchowne są przewidziane i uwzględnione. [...] Domy rekolekcyjne wydają owoce stokroć obfitsze. [...] Mniej z ludźmi, więcej z Bogiem - oto niezbędny warunek dobrych i skutecznych rekolekcji, który bez wątpienia najlepiej można spełnić w domu rekolekcyjnym. Tych dni trzy, spędzonych więcej w kaplicy i przed Bogiem jak wśród swoich lub na ulicy; tych dni trzy, poświęconych wyłącznie tylko sprawie duszy - musi stanowczo zaważyć na szali życia człowieka" ${ }^{\text {"30. }}$.

Pierwsze trzydniowe rekolekcje w kaplicy Domu Rekolekcyjnego odbyły się zaledwie dziesięć dni po poświęceniu domu i kaplicy, w dniach 18-21 grudnia 1905 roku. Prowadzili je ojcowie: Łukasz Łaszczyk, Paweł Makowski, Franciszek Smarzły i Tomasz Kuryłowicz ${ }^{31}$. Skorzystało z nich około 200 mężczyzn, z których 4 mieszkało w Domu Rekolekcyjnym ${ }^{32}$. Rekolektanci mieli do dyspozycji znaczną bibliotekę dzieł religijnych, która po śmierci jednego z księży diecezjalnych wystawiona na sprzedaż została zakupiona dla domu przez o. Łaszczyka ${ }^{33}$. Natomiast jezuici mogli poszerzać swoją wiedzę o rekolekcjach sięgając m.in. po wychodzące od 1906 roku

${ }^{28}$ W Archiwum Prowincji Polski Południowej Towarzystwa Jezusowego zachowały się egzemplarze zaproszeń w języku polskim i niemieckim na rekolekcje do Czechowic z lat 1908-1913. Czechowice-Dziedzice, Dom Rekolekcyjny, ATJKr. rkps 382, s. 47-50, 52-54, 56-84, 97, 114, 117-119.

${ }^{29} \mathrm{~K}$. Feliś, Domy rekolekcyjne $i$ dom rekolekcyiny w Czechowicach, ATJKr. rkps 1626, s. 266r-v.

${ }^{30}$ Tamże, s. 267-270.

${ }^{3 !}$ Kuryłowicz Tomasz, ur. 1861, wst. 1879, dym. 1907. Encyklopedia wiedzy o jezuitach, s. 837.

${ }^{32}$ "Nasze Wiadomości" 1 (1904-1906), s. 620; K. F eliś, Domy rekolekcyjne i dom rekolekcyjny w Czechowicach, ATJKr. rkps 1626, s. 275-276.

${ }^{33}$ S. Załęski, Jezuici w Polsce, t. V/2, s. 1130. 
w Enghien ${ }^{34}$ w Belgii czasopismo poświęcone Ćwiczeniom duchownym św. Ignacego Loyoli pt. Collection de la Bibliothèque des Exercices de Saint Ignace. Czasopismo to ukazywało się co dwa miesiące pod redakcją o. Henryka Watriganta i o. Pawła Debuchy. Do abonamentu i lektury tego czasopisma zachęcił jezuitów galicyjskich osobnym okólnikiem o. prowincjał Włodzimierz Ledóchowski ${ }^{35}$.

W 1906 roku rekolekcje odprawiło 486 mężczyzn z trzech zaborów, w tym blisko 400 Gómoślązaków, w 1907 roku 475 osób, w 1908 roku 572, a do 27 sierpnia 1909 roku 366 osób. Na szczególne podkreślenie zashuguje fakt, że w 1906 roku w liczbie 486 osób, które odprawiły rekolekcje, było aż 195 robotników z Bogucic (Górny Śląsk), którzy zgłoszeni przez ks. proboszcza Ludwika Skowronka ${ }^{36}$ odprawili rekolekcje w trzech seriach (8-11 IX, 15-18 IX i 29 IX - 2 X). Większość nauk była głoszona po polsku. Serię trzecią (29 IX $-2 \mathrm{X}$ ) prowadził w języku polskim o. Kazimierz Mielicki ${ }^{37}$. Zdaniem jezuitów ,tym razem byli żonaci wespół $\mathrm{z}$ młodzieńcami, co się okazało niepraktyczne; lepiej jest, gdy wszyscy rekolektanci są tego samego stanu" ${ }^{\prime 8}$. Informacja, że ks. Skowronek, który także w następnych latach wysyłał na rekolekcje wiernych do ,polskiego klasztoru w Dziedzicach”, spotkała się z krytyką w niemieckojęzycznej prasie na pruskim Górnym Śląsku ${ }^{39}$.

W dniach 1-4 grudnia 1906 roku rekolekcje odprawiło u jezuitów w Czechowicach 58 robotników z Kochłowic (Górny Śląsk), przysłanych przez ks. proboszcza Ludwika Trunkla. Z kolei w połowie grudnia 1906 roku (15-18 XII) odbyły się rekolekcje dla 99 robotników z Górnego Sląska, ze Śląska Cieszyńskiego, Galicji i Kongresówki. Także i w tej grupie przeważali Górnoślązacy, którzy przybyli z Lędzin,

${ }^{34}$ Wypędzeni jezuici z Francji założyli w Enghien kolegium św. Augustyna (Maison Saint-Augustin), w którym mieściło się studium teologiczne Prowincji Szampańskiej. Przy kolegium znajdowała się, zapewne jedyna w całym Towarzystwie Jezusowym, biblioteka rekolekcyjna, założona i prowadzona przez o. Henryka Watrigant (1845-1926). Zdaniem o. Tomniczaka, który odwiedził Enghien w 1910 r., o. Watrigant uchodził za najlepszego znawcę Cwiczeń duchownych św. Ignacego Loyoli. O. Tomniczak zauważył, że o. Watrigant przygotował w swoich zbiorach miejsce na materiały ukazujące działalność rekolekcyjną Prowincji Galicyjskiej. Niestety, w tym czasie było ono puste. $O$. Watrigant prosił go, aby przysłano mu historię domów rekolekeyjnych, sprawozdania roczne, prospekty i ogłoszenia, a nawet widokówki do albumu. Warto dodá́, że jeśli chodzi o dzieła z duchowości (ascetyka, mistyka, duchowość ignacjańska), biblioteka w Enghien uważana była za najlepszą w całym Towarzystwie Jezusowym. To przekonanie panowało jeszcze w 1938 r. List o. K. Dembowskiego do o. superiora S. Bednarskiego, Toulouse, 7 IX 1939, Bednarski Stanistaw. Korespondencja, ATJKt. rkps 1147-II, s. 208r.

${ }^{35}$ W. Tomniczak, Biblioteka ćwiczen duchownych św. O.N. Ignacego w Enghien, „Nasze Wiadomości” 3 (1910-1912), s. 164-176. Czasopismo Collection de la Bibliothèque des Exercices de Saint Ignace było abonowane także przez Dom Rekolekcyjny we Lwowie. Spis ksiazek kupionych lub darowanych do biblioteki Domu Rekolekcyjnego, ATJKr. rkps 1181-XI, s. 6v-7r.

${ }^{36}$ Skowronek Ludwik (1859-1934), proboszcz parafii św. Szczepana w Bogucicach (od 1889), autor modlitewnika Droga do nieba (I wyd. 1903), najbardziej rozpowszechnionego i najpopularniejszego modlitewnika wśród ludzi na Gómym Sląsku w I pol. XX wieku. J. Wycisło, Skowronek Ludwik, SBKDS, s. 378-379.

${ }^{37}$ Mielicki Kazimierz (1854-1923), profesor języka greckiego, teologii i historii Kościoła w kolegiach jezuickich, operariusz w Cieszynie, Nowym Sączu, Staniątkach, Czechowicach, Lwowie i Starej Wsi. Zmarł w Dziedzicach jako duchowny domu, kaznodzieja i spowiednik. H. Haduch, Sp. O. Kazimierz Mielicki, „Nasze Wiadomości" 7 (1923), s. 88-89; Encyklopedia wiedzy o jezuitach, s. 421.

\$. ..Nasze Wiadomości" 2 (1906-1909), s. 206.

* Cechowice-Dziedzice, Dom Rekolekcyjny, ATJKr. rkps 382, s. 87. 
Michałkowic, Chełmu, Pszczyny, Łąki, Brzeźców, Suszca, Goczałkowic i Ćwiklic, cyli z regionu nadgranicznego. W opinii prowadzącego rekolekcje o. Jakuba Krysy ${ }^{40}$ pomimo, że skład osób był liczny a przy tym niejednolity, rekolekcje odbyły się dobrze, w zgodzie i miłości iście chrześcijańskiej" "41. Oprócz rekolekcji dla robotników miały miejsce w dniach 20-24 sierpnia 1906 roku rekolekcje kapłańskie dla 31 księży diecezjalnych (w tym było 20 księży z Gómego Śląska). Prowadził je urodzony w Bytomiu o. Leopold Markefka ${ }^{42}$. Warto podkreślić, że były to pierwsze rekolekcje kapłańskie w domu czechowickim. Według jezuitów rekolekcje te „wypadły pod każdym względem dobrze. Rekolektanci zachowali wzorowo milczenie i skupienie ducha, do czego niemało przyczyniła się ta dogodność, że każdy z nich miał osobny pokój i w ogrodzie osobną ścieżkę do chodzenia, a więc nie przeszkadzał jeden drugiemu. Wszyscy byli nadzwyczaj zadowoleni i obiecali przybyć znowu za rok na rekolek-

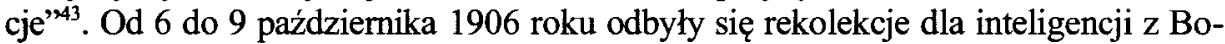
gucic. Byli to nauczyciele, urzędnicy, akademicy, artyści-malarze, sztygarzy i kupcy. Nauki w języku niemieckim miewał dla nich pochodzący z Nysy Śląskiej o. Alojzy Starker $^{44}$. Wreszcie należy podkreślić, że po pierwszej niedzieli Wielkiego Postu, w dniach od 4 do 8 marca 1906 roku, jezuici dawali rekolekcje około 800 niewiastom. Przeważały uczestniczki $z$ Górnego Śląska, które nocowały u gospodarzy czechowickich. Nauki rekolekcyjne (po 4 dziennie) głosili oo: Lukasz Łaszczyk, Paweł Makowski i Franciszek Smarzły, którzy z pomocą zaproszonych z Cieszyna oo.: urodzonego we Biedrzychowicach na Śląsku Jana Kicińskiego ${ }^{45}$ i Jana Kantego Piwernetza ${ }^{46}$, wyshuchali przeszło 600 spowiedzi, prawie wszystkie były spowiedziami generalnymi, czyli z całego życia; reszta niewiast przystąpiła do sakramentu pojednania później" ${ }^{47}$.

Dokonując oceny wszystkich serii rekolekcji przeprowadzonych w 1906 roku w Domu Rekolekcyjnym w Czechowicach, jezuici doszli do wniosku, ,że rekolekcje dla robotników najlepiej udają się wtenczas, gdy rekolektanci pochodzą z tej samej

${ }^{40}$ Krysa Jakub (1864-1942), profesor historii i geografii w Chyrowie (1893-1922), profesor Gimnazjum Św. Kazimierza w Wilnie (1922-1933) i gimnazjum jezuickiego w Pińsku (1933-1937). Encyklopedia wiedzy o jezuitach, s. 336 .

${ }^{41}$ „Nasze Wiadomości” 2(1906-1909), s. 207.

${ }^{42}$ Markefka Leopold (1851-1926), m.in. w 1891 uczestnik tajnej misji wśród unitów na Podlasiu, profesor teologii dogmatycznej w Krakowie (1893-1894 i 1901-1902) oraz Jassach (1902-1903). Kaznodzieja niemiecki i polski na wielu placówkach jezuickich, głównie na Śląsku. Encyklopedia wiedzy o jezuitach, s. 407.

${ }^{43}$ „Nasze Wiadomości” 2 (1906-1909), s. 206.

${ }^{44}$ Starker Alojzy (1868-1934), profesor języka niemieckiego i historii w Chyrowie (1888-1892), operariusz w Opawie (1900-1901) i Lwowie (1902-1903), profesor historii Kościoła, patrologii i archeologii w Krakowie (1903-1913 i 1920-1921) oraz superior w Opawie (1913-1920). W 1921 przeszedł do Prowincji Niemieckiej. Autor artykułów i recenzji o tematyce historycznej i społecznej. Encyklopedia wiedzy o jezuitach, s. 643.

${ }^{45}$ Kiciński Jan (1844-1921), operariusz i kaznodzieja polski i niemiecki, superior w Nowym Sączu (1888-1894). Tamże, s. 277.

${ }^{46}$ Piwernetz Jan Kanty (1859-1915), m.in. profesor filozofii w Krakowie (1889-1890), Tarnopolu (1890-1894), Nowym Sączu (1895-1896) i w Seminarium Duchownym w Jassach (1896-1897), kaznodzieja w Cieszynie, Tamopolu, Starej Wsi, Czerniowcach, Nowym Sączu i Czechowicach. Misjonarz wśród polskich robotników sezonowych. Tamże, s. 515.

${ }^{47}$ „Nasze Wiadomości” 2 (1906-1909), s. 205-207; J. Kwiatek, Zwiazki Górnego Śląska z Galicja na przelomie XLX i XX wieku, s. 79. 
miejscowości, a liczba ich wynosi 50-60 osób; przy większym zaś zgromadzeniu trudno utrzymać ład i milczenie w domu, trudno też obshużyć wszystkich należycie. Najdogodniej jest partię rekolektantów z jakiejś parafii organizować przez tamtejszego proboszcza, zwłaszcza gdy ten, zachęciwszy $\mathrm{z}$ ambony mężczyzn do wzięcia udziału w rekolekcjach, czas na nie wyznaczony ogłosi, następnie z pomiędzy zgłoszonych ochotników odpowiednią liczbę wybierze i prześle do Czechowic listę ich nazwisk, wraz z pobraną naprzód opłatą na utrzymanie"48.

W oparciu o wyższej przytoczone statystyki za lata 1906-1909, o. Karol Feliś pisał $\mathbf{z}$ nieukrywaną dumą, że ,jeżeli porównamy początki domu czechowickiego $\mathrm{z}$ początkami domów rekolekcyjnych za granicą, to porównanie to wypada tylko na korzyść domu czechowickiego. Udział w rekolekcjach w tych latach jest równie liczny a nawet nieraz liczniejszy jak w początkach podobnych domów rekolekcyjnych za granicą. (...) Podczas bowiem, gdy w zagranicznych domach rekolekcyjnych osobno w tym celu złożone fundusze pokrywają robotnikowi straty, spowodowane usunięciem się od pracy na czas rekolekcji, to robotnik nasz, mimo nie wynagrodzoną stratą materialną, również chętnie i licznie bierze udział w rekolekcjach"49.

$\mathrm{Na}$ zakończenie opisu działalności Domu Rekolekcyjnego w Czechowicach, o. Feliś podal kilka praktycznych wskazówek dla chcących odprawić tam rekolekcje. Okazuje się, że większość z tych uwag nie straciła nic ze swojej aktualności:

„1. Chociaż dom czechowicki pragnie przede wszystkim służyć duchowym potrzebom klasy robotniczej, mogą jednak odprawiać w nim rekolekcje osoby wszystkich warstw społecznych.

2. Rekolekcji udziela się tylko większej liczbie osób, np. 15-60 osób. Można atoli odprawiać je także pojedynczo. Należy w tỷm razie porozumieć się ustnie lub listownie $z \mathrm{ks}$. superiorem domu.

3. Rekolekcje trwają całe 3 dni, nie rachując dnia przyjazdu i odjazdu. Najpóźniej można zjechać na rekolekcje w przeddzień ich zaczęcia o godz. 7. wieczorem.

4. Na rekolekcje nie potrzeba przywozić ze sobą żadnej pościeli, bo tej dostarcza Zarząd Domu; można tylko zabrać ze sobą rzeczy, służące do toalety.

5. Za cały czas pobytu składają biorący udział $w$ rekolekcjach odpowiednie wynagrodzenie; robotnicy placą za całe utrzymanie 7 kor[on] (7 marek).

48 „Nasze Wiadomości”' 2 (1906-1909), s. 207.

${ }^{49} \mathrm{~W}$ powyższych statystykach uwzględniono jedynie osoby, które na czas rekolekcji mieszkały w Domu Rekolekcyjnym, natomiast pominięto te, które dochodziły na nauki. K. Feliś, Domy rekolekcyjne $i$ dom rekolekcyjny w Czechowicach, ATJKr. rkps 1626, s. 278-279. Dane podane przez o. Felisia różnią się nieco od późniejszych statystyk. Por. Wykaz rekolekcji zamkniętych w Domu Rekolekcyjnym OO. Jezuitów w Dziedzicach od r. 1905-1930, „Nasze Wiadomości” 10 (1930-1934), s. 40-41; Wykaz rekolekcji dawanych w domu rekolekcyjnym w Dziedzicach 1905-1920, [w:] Czechowice-Dziedzice, Dom Rekolekcyjny, ATJKr. rkps 382, s. 127; Historia domów Prowincji Galicyjskiej i Malopolskiej Towarzystwa Jezusowego, ATJKr. rkps 1353-I, s. 98-100. 


\section{Z Górnego Śląska (z Prus) jedzie się do Dziedzic przez Katowice i Pszczynę} albo przez Bogumin; ze Śląska austriackiego albo przez Bogumin, albo przez Piotrowice, albo też przez Bielsko; z Galicji albo przez Oświęcim, albo przez Żywiec na Bielsko.

7. Zgłoszenia na rekolekcje należy adresować:

Ks. Superior domu rekolekcyjnego w Dziedzicach, Śląsk austriacki”50.

Działalność Domu Rekolekcyjnego spotkała się nie tylko ze słowami pochwały pod adresem jezuitów. Ostro krytykowały ją niektóre koła polityczne w Prusach, widząc w nich celową, antypruską, politykę jezuitów galicyjskich. Jednym z krytyków działalności domu był profesor uniwersytetu w Berlinie Ludwik Bernhard, jeden z czołowych ideologów pruskiego nacjonalizmu, autor książki pt. Die Polenfrage, który 10 grudnia 1909 roku w odczycie w berlińskiej sali architektów wyrazil m.in. pogląd, że rekolekcje organizowane w Czechowicach są jednym z elementów celowej polityki galicyjskiej Kościoła, zmierzającej do wciągnięcia Górnego Śląska w sferę polskich wpływów. W podobny ton uderzała hakatystyczna prasa, przypisując inicjatywie jezuitów polityczne czy wręcz szowinistyczne zamiary. „Kattowitzer Zeitung” utrzymywał np., że celem rekolekcji jest wzniecanie „,narodowej nienawiści" ${ }^{51}$. Reakcje te można wythumaczyć tym, że niezależnie od działalności rekolekcyjnej w Czechowicach w latach 1907-1913 jezuici udzielili w parafiach na Górnym Sląsku około 190 serii polskich i niemieckich rekolekcji w 73 miejscowościach. Były to na ogół rekolekcje ludowe o charakterze otwartym oraz stanowe. Ponadto odbywały się osobne Ćwiczenia duchowne dla różnych grup zawodowych i bractw religijnych. Nierzadko, jak to było w tradycji zakonu i mając na uwadze zachowanie owoców rekolekcji oraz

\footnotetext{
${ }^{50} \mathrm{~K}$. Feliś, Domy rekolekcyjne i dom rekolekcyjny w Czechowicach, ATJKr. rkps 1626, s. 280-281.

${ }^{51}$ Oskarżanie jezuitów o prowadzenie w Domu Rekolekcyjnym w Dziedzicach agitacji przeciwko
} Niemcom oraz budzenia nastrojów polskich pojawia się w prasie pruskiej aż do wybuchu I wojny światowej. Jeszcze w lipcu 1914 r. spotykamy w „Kattowitzer Zeitung” ataki na jezuitów i prowadzony przez nich Dom Rekolekcyjny w Dziedzicach. W odpowiedzi na nie superior domu o. J. Lipski udzielił wyjaśnień w artykule pt. Die „Kattowitzer Zeitung” und die Jesuiten in Dzieditz, opublikowanym w numerze $161 \mathrm{z}$ dnia 18 VII 1914 r. na łamach gazety „Oberschlesischer Kurier”. Wypowiedź o. Lipskiego opatrzona jest uwagą redakcji „Oberschlesischer Kurier”, że „Kattowitzer Zeitung” zwalcza wszystko to, co jest katolickie, a więc także działalność rekolekcyjna jezuitów prowadzoną w Dziedzicach. Ustosunkowując się do zarzutów o działalność antyniemiecką o. Lipski podkreślił, że zaangażowanie jezuitów w Dziedzicach ma charakter wyłącznie rekolekcyjny i jest pozbawione jakichkolwiek elementów agitacji narodowej: „Wer auch nur ein einziges Mal im Exerzitienhause Dziedzitz geistliche Uebungen gemacht hat, der weiß aus eigener Anschauung und Erfahrung, daß dort alle nationale Hetze ausgeschlossen ist und nur rein religiöser Fortschritt gepflegt und gefordert wird". Kilka dni póżnicj ukazał się na łamach „Oberschlesischer Kurier” artykuł Die Angriffe der „,Kattowitzer Zeitung" gegen die Jesuiten in Dzieditz (nr $164 \mathrm{z}$ dnia 22 VII 1914 r.). Zawiera on wrażenia pewnego przyjaciela gazety, który przy okazji pobytu na kuracji w Goczałkowicach odwiedził Dziedzice oraz jezuicki Dom Rekolekcyjny. Przekonał się on na miejscu, że czterech ojców jezuitów z Domu Rekolekcyjnego urodziło się na terenach pruskiego Górnego Śląska (superior J. Lipski, L. Wilimski, F. Hübner i L. Roelle), a pozostali działają jako misjonarze ludowi. Wedhug życzenia w kaplicy jezuitów pw. św. Józefa odprawiane są Msze św. w języku niemieckim i polskim. Nie zauważył jakiejś pro polskiej agitacji: „Von einer mächtigen Agitation fürs Polnische merkte ich nichts. Ich wurde deutsch empfangen, deutsch unterhalten über deutsche Männer und Helden und deutsch entlassen". Assmann Jan T.J., ATJKr. rkps 1332-II, s. 43-44. 
stałe pogłębianie życia duchowego, podczas rekolekcji ludowych jezuici zakładali Arcybractwa Najświętszego Serca Jezusowego. W tej sytuacji Towarzystwo Jezusowe podobnie jak inne galicyjskie zgromadzenia zakonne, które łączyła duszpasterska więź z Gómym Śląskiem - stało się obiektem szczególnego zainteresowania pruskiej policji, która skrupulatnie śledziła sfery ich społecznych działan, shużące rozwijaniu polskości ${ }^{52}$.

Na przełomie 1905/1906 roku wspólnota jezuitów w Czechowicach włączyła się w uroczystości beatyfikacyjne bł. męczenników koszyckich: Melchiora Grodzieckiego (urodzony w Grodźcu na Śląsku Cieszyńskim), Stefana Pongracza i Marka Stefana Križa, umęczonych wśród wyszukanych tortur przez innowierców w początkach wojny 30-letniej w Koszycach na Węgrzech dnia 7 września 1619 roku i beatyfikowanych 15 stycznia 1905 roku przez papieża Piusa $X^{53}$. Uroczystości celebrowano jesienią 1905 roku we wszystkich kościołach Prowincji Galicyjskiej i zakończono jednodniowymi rekolekcjami w Czechowicach 14 stycznia 1906 roku (wspomnienie Imienia Jezus), na które przybyło kilku zaproszonych księży świeckich ze Śląska oraz kilku jezuitów z Krakowa, na czele z rektorem Kolegium Krakowskiego, o. Antonim Bocem. Wierni thumnie uczestniczyli w nabożeństwach, shuchali kazań o cnotach i krwawych zapasach bohaterów wiary, modlili się do nich, rozchwytywali obrazki pamiątkowe i książeczkę z opisem ich życia i męczeństwa: Blogostawieni O. Melchior Grodziecki, O. Stefan Pongracz kaplani Towarzystwa Jezusowego i Marek Stefan Križ kanonik ostrzychomski, umęczeni za wiarę św. r. 1619, zaliczeni w poczet blogoslawionych d. 15 stycznia 1905 r., wydaną w Krakowie w 1905 roku przez redaktora naczelnego jezuickich „Misji Katolickich”, o. Marcina Czermińskiego ${ }^{54}$.

Niedługo po powstaniu pierwszego w Prowincji Galicyjskiej Domu Rekolekcyjnego w Czechowicach ukazal się 16 listopada 1906 roku artykuł w krakowskim „Czasie", podpisany inicjałami X.S. i zatytułowany Zaklad w Czechowicach. Autorem artykułu przedrukowanego następnie przez czasopismo zakonne „Nasze Wiadomości” był ks. prałat Franciszek Starowieyski ${ }^{55}$, który odprawił rekolekcje w dniach 5-9 listopada 1906 roku w grupie 13 księży diecezjalnych, przeważnie ze Śląska pruskiego. Rekolekcje te prowadził w języku niemieckim o. Leopold Markefka. Kreśląc opis położenia Czechowic, Starowieyski zaznaczył, że obszerny, dwupiętrowy dom leży na austriackim Śląsku, w pobliżu Dziedzic, w małym oddaleniu od dymnych kominów fabrycznych i łoskotu warsztatów, wśród świeżo założonego i obszernego parku. Podkreślit, że w tym domu obok nielicznych członków zakonu ,przebywają kilkanaście

\footnotetext{
${ }^{52}$ J. Kwiatek, Zwiazki Górnego Ślqska z Galicjq na przełomie XIX i XX wieku, s. 80-82.

${ }^{53}$ Papież-Polak Jan Paweł II dokonał kanonizacji męczenników 2 VII 1995 r. w Koszycach. Encyklopedia wiedzy o jezuitach, s. 309-310.

${ }^{54}$ „Nasze Wiadomości” 1 (1904-1906), s. 671-672.

${ }^{55}$ Starowicyski Franciszek (1850-1924), doktor teologii i prawa kanonicznego, dyplomata watykanski, potem proboszcz parafii Wszystkich Świętych przy kościele św.św. Piotra i Pawła w Krakowie, popularyzator historii kościelnej. S. Piech, Starowieyski (Biberstein-Starowieyski) Franciszek, „Polski Stownik Biograficzny”, t. 42, s. 349-351.
} 
razy do roku zastępy robotników, którzy wśród ciężkiej pracy fizycznej spieszą pod gościnny dach, ażeby w trzydniowych ćwiczeniach rekolekcyjnych przypomnieć sobie zbawienne prawdy wiary świętej i umocnić niemi ducha, orzeźwiając go wśród ciężkiej doli życia bardzo jednostajnego, wszelkich ulg, wszelkich pociech zwykle zupełnie pozbawionego! W obszernych dormitarzach i refektarzu zasiada wówczas po sześćdziesiąt do siedemdziesięciu synów tej ubogiej i pracującej ludności, do której tym sposobem, chociaż częściowo, przystępu nie mają złowrogie niebezpieczne wpływy innych, bardzo skwapliwie działających czynników"56. Dalej ks. prałat wyjaśniał, że obok wielkich dormitarzy dla robotników, znajduje się w tym samym budynku czterdzieści cel zakonnych, przeznaczonych dla kapłanów świeckich, mogących tu odprawiać w milczeniu i skupieniu ducha prawem kościelnym przepisane rekolekcje, czyli Ćwiczenia duchowne. Chociaż nawet i wśród protestantów mówiło się o otwarciu podobnych domów rekolekcyjnych, niemniej po wnikliwej wizytacji czechowickiego domu rekolekcyjnego, ks. Starowieyski nie miał wątpliwości i czuł się utwierdzony w ,głębokim przekonaniu, iż jedynie tylko w katolickim Kościele powstawać $\mathrm{i}$ istnieć mogą wielkie dzieła życia duchowego, gdyż on jeden zna i przenika ich tajniki, że co do ich zakładania i utrzymywania pierwszeństwo dzierży Zgromadzenie Jezusowe i że nowy zakład w Czechowicach jest prawdziwym dobrodziejstwem nie tylko dla Śląska, ale i dla innych graniczących z nim okolic"57. Dwa lata później ks. Franciszek Starowieyski powtórnie przybył do Czechowic i tu w dniach 9-13 listopada 1908 roku wraz i 31 innymi kapłanami, głównie ze Śląska pruskiego i austriackiego, odprawił rekolekcje prowadzone w języku niemieckim przez urodzonego w Ruszy na Śląsku o. Jana Rothenburgera ${ }^{58}$.

Jezuicki dom rekolekcyjny odwiedzili również znakomici goście. W środę, 5 sierpnia 1908 roku, rannym pociągiem z Żywca przybył do Dziedzic mężczyzna $\mathrm{w}$ sile wieku, w ubraniu przypominającym leśniczego lub urzędnika w gospodarstwie. Na stacji najął sobie posługacza kolejowego do niesienia kuferka i kazał się zaprowadzić do domu rekolekcyjnego. Nieznajomy wszedł do kaplicy i tam modlił się przez jakiś czas. W tym czasie w kaplicy Mszę św. odprawiał ks. Józef Kartte ${ }^{59}$. Po modlitwie mężczyzna podszedł do br. Ignacego Kolegowicza ${ }^{60}$ i zapytał, w jakim języku może się z nim porozumieć. Gdy otrzymał odpowiedź, że tylko po polsku, poprosił go po polsku o księdza, przed którym mógłby odbyć spowiedź w języku niemieckim. Br.

${ }^{56}$ „Nasze Wiadomości” 2 (1906-1909), s. 206, 597-598. Por. Czechowice-Dziedzice, Dom Rekolekcyjny, ATJKr. rkps 382, s. 87.

57 „Nasze Wiadomości” 2 (1906-1909), s. 598.

${ }^{58}$ Rothenburger Jan (1848-1912), m.in. misjonarz polonijny w Stanach Zjednoczonych (1900-1906), rekolekcjonista w Krakowie (1906-1909), Czechowicach (1909-1910) i Karwinie (1910-1912). Encyklopedia wiedzy o jezuitach, s. 580; Andenken an die Priesterexercitien in Czechowitz vom 9. bis 13. November 1908 unter Leitung R. P. Joh. Rothenburger S.J., Czechowice-Dziedzice, Dom Rekolekcyjny, ATJKr. rkps 382, s. 51; „Nasze Wiadomości” 2 (1906-1909), s. 682.

${ }^{59}$ Kartte Józef, ur. 1872, wst. 1890, zm. 1942. Encyklopedia wiedzy o jezuitach, s. 830.

${ }^{60}$ Kolegowicz Ignacy (1860-1941), ogrodnik na kilku placówkach, w Czechowicach w latach 1908-1911. Tamże, s. 292. 
Kolegowicz zwrócił się do br. Franciszka Willima ${ }^{61}$, a ten przekazał prosbę o. Karolowi Nonnastowi ${ }^{62}$, jedzącemu w tym czasie śniadanie w refektarzu. Było to około godz. 7 rano. Po spowiedzi mężczyzna udał się do najbliższej lawki, a kiedy Msza św. się skończyła, poprosił o Komunię św. i z wielkim nabożeństwem oddał się modlitwie. Potem opuścił kaplicę i zaczął przed domem jeść suchą bułkę. Kiedy zobaczył to br. Willim, zaprosił Nieznajomego do rozmównicy na kawę. Mężczyzna przyjął zaproszenie, a spożywszy posiłek, wręczył bratu zamkniętą kopertę, dodając po polsku, że jest to jałmużna dla domu. Wtedy br. Willim poprosił go, aby podał swoje nazwisko i godność. Nieznajomy się wzbraniał, tłumacząc, że wolałby, by to była tajemnica, ale w końcu ulegał naleganiom brata i własnoręcznie napisał na kopercie po polsku: „Jego Cesarska Wysokość Arcyksiążę Karol Stefan ${ }^{63}$, Żywiec, zamek”.

Po ujawnieniu tajemnicy, dostojny gość zwiedził w towarzystwie brata rezydencję i sypialnię domu rekolekcyjnego, wielokrotnie chwaląc porządek, schludność i warunki higieniczne domu. Pytał się również o rekolekcje, dodając, że przy nadarzającej się okazji sam pragnie wziąć w nich udział oraz przysłać tu swoich robotników. Po zwiedzeniu domu, arcyksiążę powrócił do kaplicy, aby tam odmówić różaniec. Tymczasem wieść o obecności dostojnego gościa dotarła do pozostałych domowników, którzy zgromadzili się u drzwi kaplicy, aby powitać Jego Cesarską Wysokość. W tym czasie brat kucharz przygotował gościowi obfite śniadanie. Gdy gość wyszedł z kaplicy, został zaproszony do refektarza, gdzie przedstawiono mu wszystkich jezuitów. Gość przyjął zaproszenie bez żadnej wymówki i z dobrym apetytem spożył, co mu podano. Potem zapalił ofiarowanego mu papierosa, rozmawiając swobodnie $z$ jezuitami przez całą godzinę, jakby był ich dobrym znajomym lub przyjacielem żyytym $\mathrm{z}$ nimi od wielu lat. W rozmowie wypytywał o prace jezuitów ${ }_{2}$ interesowały go nawet misje afrykańskie. Na pożegnanie wyraził zadowolenie $\mathrm{z}$ tego, że mógł się wyspowiadać oraz pogwarzyć z jezuitami. Nie przyjął ofiarowanego mu powozu i około $11^{15}$ pożegnawszy się bardzo serdecznie ze wszystkimi, w towarzystwie posługacza kolejowego niosącego jego kuferek, pieszo powrócił na dworzec kolejowy w Dziedzicach. Jezuici byli pod wrażeniem gorącej i żywej wiary arcyksięcia oraz jego swobody graniczącej z poufałością w obcowaniu z nimi. Po powrocie ze Śląska, o. superior Józef Lipski, podziękował serdecznie arcyksięciu za jego hojność i dobroć. W odpowiedzi arcyksiążę Karol Stefan wysłał z Żywca list dziękczynny, pełen serdecznych wyrazów pod adresem jezuitów ${ }^{64}$.

${ }^{61}$ Willim Franciszek, ur. 1880, wst. 1903, zm. 1912. Tamże, s. 870.

62 Nonnast Karol (1851-1916), wychowawca i nauczyciel w Tarnopolu (1875-1879 i 1882-1886) oraz w Chyrowie (1886-1899 i 1908-1909), profesor języka niemieckiego w Starej Wsi (1899-1907). Tamże, s. 461.

${ }^{63}$ Karol Stefan Habsburg (1860-1933), arcyksiążę, admirał floty austriackiej i wlaściciel dóbr żywieckich, w czasie I wojny światowej był kandydatem na tron polski. A. Galos, Karol Stefan Habsburg, „Polski Słownik Biograficzny", t. 9, s. 219. Także później trwały przyjacielskie związki rodu książąt Habsburgów z Żywca z jezuitami. Arcyksiążę Karol Habsburg był jednym z najgorętszych przyjaciół Związku Młodzieży Przemysłowej i Rękodzielniczej, założonego w Krakowie przez o. Mieczysława Kuznowicza. Kraków. Zwiazek Modzieży Przemyslowej i Rękodzielniczej, „Wiadomości z Prowincji” 6 (10) (1936), s. 6-7.

${ }^{64}$ K. Nonnast, Arcyksiaże w Czechowicach, „Nasze Wiadomości” 2 (1906-1909), s. 746-747; Historia domów Prowincji Galicyjskiej i Malopolskiej Towarzystwa Jezusowego, ATJKr. rkps 1353-I, s. 100. 
O atmosferze panującej podczas odprawiania rekolekcji zamkniętych oraz o ich programie w Domu Rekolekcyjnym w Dziedzicach dowiadujemy się z artykułu zatytułowanego Wrażenia z rekolekcyi odprawionych w Dziedzicach, podpisanego przez bezimiennego rekolektanta ${ }^{65}$. Na wstępie autor artykułu zaznacza, że słowo „rekolekcje” wywołuje przerażenie i wszelkiego rodzaju najstraszniejsze wyobrażenia u tych, Itórzy je znają jedynie ze słyszenia, natomiast jest miłe, wzniosłe i wywołuje pamięć dni najpiękniejszych u tych szczęśliwych, którym Pan Bóg dał tę łaskę, że mogli uczestniczyć w Ćwiczeniach duchownych. Rekolektant stwierdził z ubolewaniem, że Jiczba takich, którzy o rekolekcjach nic wiedzieć nie chcą, jest wielka, daleko więkša, niż liczba ich zwolenników. A jednak, jakżeż inaczej byłoby wśród ludzi, jakżeż inaczej przedstawiałoby się całe społeczeństwo, gdyby duch rekolekcji wszystkich przenikną!!"66. Dalej autor artykułu przyznał, że także i on odnosił się początkowo $z$ dużym sceptycyzmem do rekolekcji, lecz w końcu udał się na nie uległszy namowom swojego przyjaciela i kolegi, który przekonywał go tymi słowami: „Zaszkodzić to nam nie zaszkodzi, a wzbogacimy się o jedno doświadczenie więcej; będziemy przynajmniej wiedzieli, czym są właściwie te rekolekcje"67.

Obydwaj panowie zostali przyjęci bardzo uprzejmie przez jezuitów. Każdy otrzymał własny, wygodny, jasny pokój, ogrzewany centralnie. W każdym pokoju na stole leżała książeczka Tomasza à Kempis $O$ naśladowaniu Chrystusa ${ }^{68}$ oraz znakomita - zdaniem autora - książka do nabożeństwa Droga do nieba ${ }^{69}$. Rekolektant przekonał się także naocznie, że „tortur, włosiennicy, dyscypliny nigdzie ani śladu"70. Rekolekcje trwały od poniedziałku wieczora do piątku rano i chociaż odbywały się w ścisłym milczeniu, to jednak odprawiający rekolekcje przyjął ten warunek $\mathrm{z}$ radością: ,Jakże nam $z$ tym dobrze! $!^{71}$. W milczeniu i skupieniu rekolektanci przechadzali się po obszernym ogrodzie, oderwani od życia codziennego, od swoich zajęć i obowiązków, od rodziny i przyjaciół, od książek i gazet. Pozostawiwszy to wszystko za

${ }^{65}$ Jest to przedruk artykułu napisanego przez jednego z uczestników rekolekcji w domu rekolekcyjnym w Dziedzicach, zamieszczonego w dodatku do nr 51, wychodzącej w Bytomiu gazety katolickiej „Oberschlesische Zeitung” z dnia 3 III 1912 r. „Nasze Wiadomości” 3 (1910-1912), s. 560-562.

${ }^{66}$ Tamże, s. 560.

${ }^{67}$ Tamże.

${ }^{68}$ Od czasów Manresy (1522-1523) O naśladowaniu Chrystusa była ulubioną książeczką św. Ignacego Loyoli, zwaną przez niego perłą ksiąg duchownych. Podczas odprawiania Ćwiczeń duchownych Ignacy zalecał lekturę O naśladowaniu Chrystusa, Ewangelii i żywotów świętych (Ćwiczenia duchowne, nr 100). Pisma Wybrane, t. I, Kraków 1968, s. 150, 236, 248.

${ }^{69}$ Chodzi tu zapewne o modlitewnik w języku polskim wspomnianego ks. Ludwika Skowronka. Ten sam tytuł nosi także książa do nabożeństwa pióra o. Jozafata Zaleskiego (Zalewski) (1785-1868), po wyrzuceniu z Rosji w 1820 m.in. profesor gramatyki i filologii łacińskiej w Tamopolu (1822-1832), a następnie historii Kościoła w Nowym Sączu (1832-1837), kaznodzieja we Lwowie (1837-1839) i Tarnopolu (1841-1848), prefekt studiów w Nowym Sączu (1839-1841). W czasie rozproszenia jezuitów misjonarz arcybiskupa lwowskiego Łukasza Baranieckiego (1848-1858) oraz rekolekcjonista w Tarnopolu (1863-1868). K. Estreicher, Bibliografia polska XIX. stulecia, t. V, wyd. 2, Kraków 1967, s. 174. S. Załęski, Jezuici w Polsce, t. V/2, s. 1151; Encyklopedia wiedzy o jezuitach, s. 779; J. Wycisło, Skowronek Ludwik, SBKDS, s. 378.

${ }^{70}$ „Nasze Wiadomości” 3 (1910-1912), s. 560.

${ }^{71}$ Tamże, s. 560. 
sobą, zajmowali się jedynie tematem: Bóg - człowiek, Stwórca - stworzenie. Tutaj też mieli sposobność do poświęcenia całych trzech dni wyłącznie swej nieśmiertelnej duszy.

Bezimienny rekolektant podał także porządek dzienny obowiązujący w czasie rekolekcji w Domu Rekolekcyjnym w Dziedzicach:

5.30 Wstanie. Modlitwa poranna w kaplicy.

6.00 Msza św. w kaplicy.

7.00 Śniadanie. Czas wolny.

7.45 I. Rozważanie w sali rekolekcyjnej. Zastanowienie się. Czas wolny.

9.30 Czytanie duchowne w sali.

10.00 II. Rozważanie. Zastanowienie się. Czas wolny.

11.45 Rachunek sumienia w kaplicy.

12.00 Obiad. Nawiedzenie Najświętszego Sakramentu?. Rekreacja.

14.00 Droga krzyżowa

15.00 III. Rozważanie w sali rekolekcyjnej.

16.00 Podwieczorek. Czas wolny.

17.00 IV. Rozważanie. Zastanowienie się.

18.30 Różaniec w kaplicy.

19.00 Kolacja. Nawiedzenie Najświętszego Sakramentu. Rekreacja.

20.00 Błogosławieństwo Najświętszym Sakramentem w kaplicy.

Modlitwy wieczorne.

Spoczynek.

Odprawiający rekolekcje spożywali śniadanie, obiad, podwieczorek i kolację wspólnie w jadalni. „Troskliwi o nas Ojcowie nie pozwalają nam zaznać głodu”podkreślił rekolektant ${ }^{73}$. Zarówno dusza, jak i ciało ma dostateczną opiekę.

Autor artykułu podał także tematy rozważań podawanych przez jezuitów. Należą one do podstawowych medytacji Ćwiczeń duchownych i duchowości ignacjańskiej: człowiek a jego cel i koniec; człowiek i inne stworzenia; grzech wobec Boga; grzech w świetle rozumu, piekła; nasza śmierć; miłosierdzie Boże ${ }^{74}$; spowiedź św.; modlitwa; Najświętszy Sakrament Ołtarza; nabożeństwo do Matki Bożej.

${ }^{72}$ Zwrócenie przez jezuitów polskich szczególnej troski duszpasterskiej na klasę robotniczą oraz szerzenie kultu eucharystycznego widoczne jest m.in. w działalności o. Wawrzyńca Tomniczaka, który w liście z 23 II 1909 r. poinformował o. prowincjała Włodzimierza Piątkiewicza o zorganizowaniu pierwszej nocnej adoracji Najświętszego Sakramentu dla robotników w Stanisławowie, która trwała od godz. 21.00 do 5 rano. Inicjatywa adoracji, podczas której o. Tomniczak wygłosił kazanie oraz prowadził różne modlitwy a na zakończenie odprawił Mszę św., wyszła od robotników z tamtejszych warsztatów kolejowych. Tamże, s. 105-106.

${ }^{73}$ Tamże, s. 561. Zachowały się programy rekolekcji w języku niemieckim i łacińskim, w których zawarto także program dnia na dzień rozpoczęcia i zakończenia rekolekcji. Program rekolekcji w języku niemieckim opatrzony jest motto: „Alles erneuern in Christo" (odnowić wszystko w Chrystusie). Natomiast napisany $w$ języku łacińskim porządek dzienny (ordo diurnus) rekolekcji dla kapłanów zawiera motto $z$ księgi proroka Ozeasza 2, 16: „Ducam eam in solitudinem: et loquar ad cor eius” (Na pustynię ją wyprowadzę i będę mówił do jej serca). Czechowice-Dziedzice, Dom Rekolekcyjny, ATJKr. rkps 382, s. 55, 64, 101.

${ }^{74}$ Warto zwrócić uwage, że temat miłosierdzia Bożego występuje w rekolekcjach ignacjańskich przed objawieniami Pana Jezusa Miłosiernego św. Faustynie Kowalskiej (1905-1938). 
Zachęcając do udziału w rekolekcjach zamkniętych, autor artykułu zaznaczył, że informacje o nich można znaleźć w prasie, bądź u swojego proboszcza. Nie ukrywał przy tym, że chociaż niejedna osoba przekracza progi dziedzickiego domu rekolekcyjnego $z$ lękiem i niepewnością, to opuszcza je ze szczęściem i weselem w duszy. Jest to rezultat odprawionej tradycyjnie pod koniec rekolekcji ignacjańskich spowiedzi generalnej, którą, jeśli sobie ktoś życzy, można odprawić w pokoju spowiednika, bez konfesjonału. „Tutaj możesz zrzucić z serca wszystko to, co cię przygniata; tutaj możesz wynurzyć wszystko to, co cię boli i dręczy. Inaczej tutaj, niż wśród ścisku około konfesjonału w twym kościele parafialnym, gdzie cię każdy zna i widzi. W spowiedzi rekolekcyjnej jest człowiek rzeczywiście sam na sam z Bogiem! I znowu staje ci się lekko i błogo na duszy, święte wesele i uszczęśliwiający pokój przepełnia serce. Skarb to zaiste nieoceniony!"75.

Ostatni dzień rekolekcji, które były godzinami spędzonymi z Chrystusem na górze Tabor i równocześnie godzinami najczystszego szczęścia, przyniósł autorowi najpiękniejszą chwilę. W tym dniu, przed powrotem do domu i codzienności, odprawiający rekolekcje wstali o godz. 5.00, aby pół godziny później wysłuchać ostatniej nauki rekolekcyjnej, a następnie o godz. 6.00 uczestniczyć we Mszy św. odprawionej przez prowadzącego rekolekcje. Autor nie zawahał się wyznać, że „,moim najszczęśliwszym dniem był dotąd ten dzień, kiedy po odprawieniu rekolekcji mogłem przyjąć Jezusa i Zbawiciela mojego, kiedy mogłem przytulić się do pełnego miłości Bożego Serca. Zaiste, przedsmak to nieba!"’76. Na koniec autor artykułu przypomniał, że także niewiasty mogą się wybrać na rekolekcje do Dziedzic, albowiem zaledwie 5 minut drogi od dworca kolejowego leży klasztor Sióstr Felicjanek, w którym jezuici z Domu Rekolekcyjnego prowadzą rekolekcje dla kobiet. Niektóre $\mathrm{z}$ nich dochodziły na nauki $\mathrm{z}$ domów prywatnych ${ }^{77}$.

Jak już wspomnieliśmy, obok jezuitów zaangażowanych w dawanie rekolekcji zamkniętych w Domu Rekolekcyjnym w Czechowicach, przebywała tam również grupa jezuickich misjonarzy ludowych, pracująca głównie na Górnym Śląsku i Śląsku Cieszyńskim (druga grupa misjonarzy przebywała w lwowskim Domu Rekolekcyjnym). Zadaniem tej grupy było także finansowe wsparcie działalności Domu Rekolekcyjnego ${ }^{78}$.

Pierwszym jezuitą zmarłym we wspólnocie Domu Rekolekcyjnego był duchowny domu w latach 1909-1910 i 1911-1914, o. Wacław Titz. Ten wspaniały mówca rekolekcyjny, a zarazem wielki asceta, odszedł do Pana 4 kwietnia 1914

75 „Nasze Wiadomości” 3 (1910-1912), s. 561-562.

${ }^{76}$ Tamże, s. 562.

${ }^{77}$ K. Feliś, Domy rekolekcyjne i dom rekolekcyjmy w Czechowicach, ATJKr. rkps 1626, s. 278. Placówka Zgromadzenia Sióstr Felicjanek w Czechowicach powstała w 1902 r. Celem zgromadzenia założonego przez bł. ojca Honorata Koźmińskiego i bł. Zofię Truszkowską jest wychowanie dzieci i młodzieży oraz opieka nad chorymi i ubogimi. T. Kasperek, Rozwój i dzialalność zeńskich zgromadzeń zakonnych $w$ diecezji katowickiej, „Nasza Przeszłość" 44 (1975), s. 216.

${ }^{78}$ Diariusz Domu Towarzystwa Jezusowego w Dziedzicach 1940-1949, ATJKr. rkps 3292, s. 3. 
roku, w 83. roku życia i 61. powołania zakonnego ${ }^{79}$. Tego samego roku. wraz z wybuchem I wojny światowej, kończy się pierwszy okres działalności Domu Rekolekcyjnego. Wojna początkowo zahamowała a następnie uniemożliwiła prowadzenie pracy rekolekcyjnej. Przez jakiś czas dom w Dziedzicach był wykorzystany przez wojsko austriackie. Zniszczeniu uległo wyposażenie domu, zastawy stołowe, pościel, bielizna, biblioteka, ogrodzenia domu ${ }^{80}$. Jezuici ponownie podjęli pracę na polu udzielania Ćwiczeń duchowych po zakończeniu I wojny światowej, która przyniosła Polsce upragnioną po 123 niewoli niepodległość. Owocną działalność przerwała II wojna światowa, która wyrządziła duże straty wspólnocie Domu Rekolekcyjnego. Wszyscy ojcowie i bracia przeszli przez niemieckie więzienia i obozy koncentracyjne, w których niektórzy $\mathrm{z}$ nich stracili życie. Po zakonczeniu wojny jezuici znowu zaczęli udzielać Ćwiczeń duchowych. Niestety już po kilku latach władze komunistyczne zaczęły utrudniać im prowadzenie działalności rekolekcyjnej. Istniało także zagrożenie konfiskaty Domu Rekolekcyjnego. Sytuacja uległa zmianie dopiero w latach 80. XX wieku, a zwłaszcza po 1989 roku. na skutek przemian zainicjowanych przez NSZZ „Solidarność"81. Odtąd dzieło rekolekcji ignacjańskich prowadzone jest w Domu Rekolekcyjnym z dużym dynamizmem, nie brak też osób, którzy chętnie korzystają z odnowy duchowej w domu, który liczy sobie już ponad 100 lat.

${ }^{79}$ Titz Wacław (1830-1914), m.in. profesor filozofii, teologii dogmatycznej, moralnej i porównawczej w kolegiach jezuickich, instruktor III probacji w Starej Wsi (1887-1888 i 1894-1895), duchowny i profesor teologii morainej w Seminarium Duchownym w Jassach (1898-1899) i Seminarium Duchownym w Widnawie (1899-1909), duchowny w Krakowie (1910-1911). Encyklopedia wiedzy o jezuitach, s. 694; Diariusz Domu Towarzystwa Jezusowego w Dziedzicach 1940-1949, ATJKr. rkps 3292, s. 4-5.

${ }^{80}$ J. Pachucki, $Z$ domu rekolekcyjnego w Dziedzicach, „Nasze Wiadomości” 7(1923-1925), s. 400.

${ }^{81}$ S. Cieślak, Losy jezuitów $i$ ich Domu Rekolekcyjnego w Czechowicach-Dziedzicach w czasie II wojny światowej,,Rocznik Wydziału Pedagogicznego Wyższej Szkoły Filozoficzno-Pedagogicznej Ignatianum w Krakowie" 2006, s. 93-110; tenże, Dzialalność Domu Rekolekcyjnego OO. Jezuitów w Czechowicach-Dziedzicach w latach 1945-1949, [w:] Towarzystwo Naukowe Księży Jezuitów w Krakowie. Prace 1950-2008 , red. R. Janusz, Kraków 2008, s. 57-80. 